\title{
Environmental Discourses and Water Law: a Case Study of the Regulation of the Murray-Darling Basin
}

\section{Discursos Ambientais e Direito da Água: um Estudo da Regulamentação da Bacia Hidrográfica de Murray-Darling}

\author{
Sally Ashton ${ }^{1}$ \\ Elena Aydos ${ }^{1}$ \\ ${ }^{1}$ University of Newcastle, Newcastle, NSW, Australia
}

\begin{abstract}
The Murray-Darling Basin, in southeastern Australia, comprises 14 per cent of Australia's geography. This paper examines some of the historical and contemporary discourses that have been deployed in the last 120 years in managing the complex challenges of the Basin. Differently to prior Indigenous practices, prevailing environmental discourses in this period have highlighted the disconnect between humans and their environment. Whilst Ecologically Sustainable Development underpins the objects of the Water Act 2007 (Cth), it is evident that, in fact, it is an economic rationalism discourse that has been deployed to regulate environmental outcomes through the marketisation of water rights.
\end{abstract}

Keywords: Water regulation, Environmental discourses. Murray-Darling Basin.
Resumo: A bacia hidrográfica de Murray-Darling, localizada no sudeste da Austrália, compreende $14 \%$ do território Australiano. O presente artigo examina os discursos ambientais que informaram a regulamentação ambiental da Bacia nos últimos 120 anos. Contrariando práticas indígenas locais, os discursos ambientais predominantes nos últimos 120 anos destacam a desconexão entre os seres humanos e seu meio ambiente. Enquanto o Desenvolvimento Ecologicamente Sustentável encontra-se entre os objetos da Lei Federal da Água de 2007, é evidente a prevalência do racionalismo econômico na regulamentação da bacia hidrográfica por meio da comercialização dos direitos da água.

Palavras-chave: Direito da água. Discursos ambientais. Murray-Darling Basin.

Recebido em: 02/12/2019

Revisado em: 13/12/2019

Aprovado em: 17/12/2019 


\section{Introduction}

The Murray-Darling Basin is situated in the south-east of Australia, and encompasses 14 per cent of Australia's total land mass. ${ }^{1}$ It is known as 'the food bowl of the nation', with an agricultural industry worth an annual \$24 billion. $^{2}$ In the last 120 years, particularly, it has been subject to increasing pressures due to the demands on the river systems for water for agriculture and other industries. This has resulted in substantial environmental harm, and precarity for those living within the environment. When up to a million fish died as the result of an algal bloom on the Darling River at Menindee at the end of $2018,{ }^{3}$ the challenges and complexities of managing a fragile river system were highlighted.

Crucial to understanding the processes of management is an understanding of the discourses that inform different approaches. A discourse is a particular shared way of understanding the world, built on language, that is used to interpret information and experiences. ${ }^{4}$ There is often more than one discourse competing in any given arena, ${ }^{5}$ and this is the case with a multiplicity of environmental approaches to the management of the Murray-Darling Basin.

The law, as well as politics, concerning the Basin is not devoid of these discursive influences, and indeed, are instrumental in enforcing the prevailing approaches, both through policy and legislation. This paper analyses the most important discourses present in contemporary

\footnotetext{
${ }^{1}$ Gerry Bates, Environmental Law in Australia (Lexis Nexis Butterworths, 10th ed, 2019) 502.

2 'Discover the Basin', Australian Government: Murray-Darling Basin Authority (Webpage) https://www.mdba.gov.au/discover-basin.

${ }^{3}$ Rhys Carman and Sara Tomevska, 'A million dead fish in 'distressing' outback algal bloom at Menindee', $A B C$ News (Webpage, $15^{\text {th }}$ January 2019). https://www.abc.net.au/ news/2019-01-08/second-fish-kill-in-darling-river-at-menindee/10696632.

${ }^{4}$ Brad Jessup and Kim Rubenstein, Environmental Discourses in Public and International Law (Cambridge university Press, 2012) 4.

${ }^{5}$ For example, there are different discourses, or ways of thinking and talking about fields such as politics, mental health, education, law enforcement, etc.
} 
environmental management, and pertinent to environmental law in the Murray-Darling Basin, through the lens of environmental discourses, as articulated by John Dryzek (Section two). ${ }^{6}$ Section three present a brief history of the Murray-Darling Basin, along with a discussion of historical discourses that have informed the political and legal approaches, both historically and currently. Section three examines the shift towards the discourse of ecologically sustainable development that has occurred subsequent to 1990, and the influence of the discourse of economic rationalism in the mechanisms to regulate the objects of the Water Act 2007 (Cth). ${ }^{7}$ The paper concludes that the discourse of ecologically sustainable development has likely given way to the discourse of economic rationalism, resulting in a lower prioritisation overall for environmental health outcomes.

\section{Environmental Discourses}

There are many competing discourses within the field of environmentalism. They exist on a spectrum that range from those that deny any permanent damage to the environment to those who warn of impending doom and the imminent destruction of our planet. In the middle are those who, through a variety of approaches, recognise that some action is required to protect the earth's environment, although these vary significantly in motivation and effectiveness.

John Dryzek, in his book 'Politics of the Earth', ${ }^{8}$ has identified many of these approaches and has categorised them in terms of either prosaic or imaginative. He has further delineated these approaches within either a reformist or radical apprehension of engagement. ${ }^{9}$

A reformist approach seeks to work within existing social and institutional frameworks to bring about change, and this encompasses the discourses of problem solving and sustainable development. Within the

\footnotetext{
${ }^{6}$ John S. Dryzek, Politics of the Earth (Oxford University Press, $3^{\text {rd }}$ ed. 2013).

${ }^{7}$ Water Act 2007 (Cth).

${ }^{8}$ Dryzek (n 6)

${ }^{9}$ Ibid 16
} 
discourses of problem solving are three different approaches that assume the status quo of current political-economic approaches but recognise the need to address environmental problems. They are administrative rationalism, democratic problem-solving and economic rationalism. Sustainability seeks to provide a more integrated approach between human interests and the interests of the environment. This approach is influenced from the international to the local level and has gained greater currency in more recent times. It is these that will be primarily discussed in this thesis. A more radical approach advocates for the dismantling and reimagining of those social and institutional frameworks because they perpetuate the continued destruction of earth's environment. Finally, there is a discourse that questions whether any long-term environmental harm is occurring at all, and is important to consider because, although in the minority, they provide a loud and powerful counterbalance to environmental reform. Following is a discussion of the discourses of problem solving, sustainability, and those sceptical of environmental harm.

\subsection{Discourses of Problem Solving}

The discourses of problem-solving focus on the enacting of environmental public policy by governments, whether by an administrative approach, an inclusive approach where citizens are able to contribute, or by a market-based approach.

\subsubsection{Administrative Rationalism}

Prior to the mid-twentieth century, awareness of environmental issues was not generally prominent in the language and practices of either governments or the wider population. However, as they rose to the fore, it seemed taken for granted that they should be managed at a governmental level. ${ }^{10}$ Dryzek defines administrative rationalism as,

[...] a problem-solving discourse which emphasises the role of the expert rather than the citizen or producer/consumer in

${ }^{10}$ Ibid 76. 
social problem solving, and which stresses social relationships of hierarchy rather than equality or competition. ${ }^{11}$

Administrative rationalism may utilise a suite of institutions and practices to manage environmental issues within a framework of expertise, rather than from a constituent perspective. These include professional natural resource management bureaucracies, ${ }^{12}$ pollution control agencies; ${ }^{13}$ regulatory policy instruments; ${ }^{14}$ expert advisory commissions; ${ }^{15}$ rationalistic policy analysis techniques; ${ }^{16}$ planning; ${ }^{17}$ and environmental impact assessment, ${ }^{18}$ although this last one does provide scope for public input. ${ }^{19}$

Administrative rationalists are ultimately motivated by the public interest. ${ }^{20}$ This notion of the public interest is arguably one-dimensional in that it is identified by the 'best available expertise' and does not include participatory engagement. It is focused on the rational management of a pre-defined and unitary formulation of what, in fact, constitutes the public interest. $^{21}$

\footnotetext{
${ }^{11}$ Ibid 75 .

${ }^{12}$ Emphasising the scientific management of natural resources in order to maximise the efficiency and yield of particular resource systems.

${ }^{13}$ One of the most enduring forms of environmental management, these agencies claim scientific expertise to manage the issues of air, land and water pollution.

${ }^{14}$ For example, the mandatory use of unleaded petrol; or so-called 'nudge' strategies such as making recycling bins larger than general waste bins.

${ }^{15}$ Such as the Climate Commission in Australia, established in 2011 (and subsequently abolished in 2013).

${ }^{16}$ Including techniques such as cost-benefit analyses and risk analyses, as well as other forecasting methods that assess the likely outcomes of policy development and decisions.

17 The 'top-down' planning practices (as opposed to other types of planning), where targets and specified actions are controlled and deployed by a centralised body.

18 These are now legally required for many courses of development or action that will impact the environment. In NSW, this is required by the Environmental Planning and Assessment Act 1979 (NSW). In some cases, Commonwealth consent may also be required by the Environment Protection and Biodiversity Conservation Act 1999 (Cth)

${ }^{19}$ Dryzek (n 6) see 76-8.

${ }^{20}$ Ibid 90.

${ }^{21}$ Ibid 88 .
} 
The main limitation of administrative rationalism is its centralised, hierarchical nature. Whilst this may have proved valuable in dealing with environmental issues prior to the late $20^{\text {th }}$ century, its structure cannot stand up to the complexity of many current environmental issues, ${ }^{22}$ where '... relevant knowledge is dispersed and fragmentary. The closed, hierarchical style of administrative rationalism has no way to aggregate these pieces of knowledge in intelligent fashion' ${ }^{23}$

Its structure also inhibits the communication of learning upwards through the hierarchy which means that those at the top may be unable or unwilling to access the latest information due to time-restraints and information processing resources. ${ }^{24}$ Additionally, problem solving may disintegrate into problem displacement as may be seen where a reduction in air pollution creates an increase in water pollution. ${ }^{25}$ Overall, administrative rationalism, Dryzek contends, has largely 'run out of steam $^{26}$ and has had to take its place within the rise of several other discourses.

\subsubsection{Democratic Pragmatism}

Democratic pragmatism is a more decentralised approach to the problem solving of environmental issues. Dryzek observes that, 'democratic pragmatism may be characterised in terms of interactive problem solving within the basic institutional structure of liberal capitalist democracy' ${ }^{27}$ This discourse asserts the engagement of all interested citizens, on an equal footing, in the course of problem solving in society.

This necessarily requires a more flexible and networked approach than that preferred by the administrative rationalists. Whilst the public interest is still at the core of this approach, there may now be multiple conceptions of it and these differing interests are often ripe for

\footnotetext{
22 Ibid 93.

${ }^{23}$ Ibid 94.

${ }^{24}$ Ibid 98.

${ }^{25}$ Ibid 94.

${ }^{26}$ Ibid 93.

${ }^{27}$ Ibid 99.
} 
manipulation by activists from all sectors of the community, including corporate and industrial interests, labour unions and social media. ${ }^{28}$ This approach may utilise practices of public consultation ${ }^{29}$; alternative dispute resolution ${ }^{30}$; policy dialogue; ${ }^{31}$ lay citizen deliberation; ${ }^{32}$ public enquiries; ${ }^{33}$ and freedom of information. ${ }^{34},{ }^{35}$

The strength of this approach is that it demonstrates that effecting change is not contingent on constitutions and formal divisions of responsibility, but rather, in informal, interactive processes. ${ }^{36}$ In theory, it is accessible by all citizens, with an ability to have grassroots input into policy decisions. However, the reality, not unsurprisingly, is somewhat different. Some voices are given greater weight than others, and powerful

\footnotetext{
${ }^{28}$ Ibid 120.
}

${ }^{29}$ One of the most obvious devices for public consultation is the Environmental Impact Assessment where, in theory, opportunity for public comment is provided. However, this may not mean that all concerns expressed by the public are ultimately taken into account by consent authorities.

${ }^{30}$ ADR provides a mechanism by which all interested parties may seek to resolve differences through the process of mediation, where a win-win outcome is more likely than a court judgement which is a zero-sum outcome. This process is more accessible, quicker and cheaper than proceeding with court action, providing a practicable forum for resolution of issues.

${ }^{31}$ This approach is evidenced by the establishment of the Ecologically Sustainable Development Process initiated by then Prime Minister, Bob Hawke in 1990. He drew together major environmental groups to develop policy recommendations. Although this was disbanded after Paul Keating became Prime Minister, this approach has been replicated with greater impetus, particularly in light of the 'Local Agenda 21' emerging from the UN Conference in Rio in 1992.

${ }^{32}$ Unfortunately, this has not had a successful history in Australia. In 2010, Prime Minister, Julia Gillard, tried to implement a citizen's assembly on climate change but later abandoned it following criticism that it was a front for lack of policy on the part of the government.

${ }^{33}$ Providing 'a visible forum where proponent and objectors alike can make depositions and arguments' (Dryzek 106). They may be constrained by their terms of reference, as well as the accessibility of all interested parties to the enquiries.

${ }^{34}$ Freedom of information laws in Australia may assist in some cases regarding government decisions, however, there are exceptions to this.

${ }^{35}$ Dryzek (n 6) see 101-8.

${ }^{36}$ Ibid, see 108-9, 112. 
interests can skew policy and decision making, particularly when operating with strategies requiring a great amount of financial and other resources. ${ }^{37}$ Business has a privileged position in these dialogues, because governments are motivated to maintain business confidence and keep the economy growing. ${ }^{38}$ Finally, conflicting conceptions of 'the public interest' across differing spheres of influence can slow or mire progress in achieving constructive solutions to environmental problems, and limit the ongoing overall effectiveness of this approach.

\subsubsection{Economic Rationalism}

The economic rationalism environmental discourses rose to prominence in tandem with the rise of neoliberalism in the last 30 years. Dryzek describes this approach as the 'commitment to the intelligent deployment of market mechanisms to achieve public ends' ${ }^{39}$ Economic rationalism approaches exist on a spectrum. At one end, advocates call for everything to be privatised to maximise the value and outcomes of private, rather than public property; and the only role of government, in this respect, is to facilitate and enforce private property rights. ${ }^{40}$ Proponents advocate that the power of the market is compelling in its capacity to shift individual and institutional preferences and practices. ${ }^{41}$

Other, less hard-line approaches see the role of government as instrumental in managing markets or providing quasi-market incentives to mediate environmental issues. ${ }^{42}$ These may take the shape of emission trading schemes, where levels of pollution are capped, and then 'rights to pollute' are commodified and traded: ${ }^{43}$ emission offset programs, where

\footnotetext{
${ }^{37}$ Ibid 118.

${ }^{38}$ Ibid 120.

${ }^{39}$ Ibid 122.

${ }^{40}$ Ibid, see 124-9.

41 Ibid 123.

42 Ibid 129.

${ }^{43}$ See Sven Rudolph, Elena Aydos, Takeshi Kawakatsu, and Achim Lerch , 'How to Build Truly Sustainable Carbon Markets' (2018) 9(1) Solutions, https://www. thesolutionsjournal.com/article/build-truly-sustainable-carbon-markets/; and Sven Rudolph and Elena Aydos, 'And Justice for All! Or: Justice in carbon market design:
} 
an environmental harm in one location is offset by an environmental benefit in another; ${ }^{44}$ and tradeable quotas, for example in fisheries, where quotas are established by the government and then traded in the marketplace. ${ }^{45}$

Critics say that these mechanisms fail to address the underlying problems of consumption, which are central to the continued growth of the economy. ${ }^{46}$ It has also been argued that this discourse subordinates the environment to the interests of homo economicus (economic man) and the mechanics of the market, with the promise of greater freedom from regulation. ${ }^{47}$

\subsection{Discourse of Sustainable Development}

Sustainable development has become the prominent ecological discourse in the last four decades. Although evident in years prior to this, it was raised to international prominence with the release of the Brundtland Commission Report in 1987, titled 'Our Common Future'. ${ }^{48}$

The report 'developed a vision of the simultaneous and mutually reinforcing pursuit of economic growth, environmental improvement, population stabilisation, peace, and global equity, which could be maintained in the long term', issues that had never been addressed concurrently before. ${ }^{49}$ In defining sustainable development, Brundtland

Insights from Theory and Experiences "Down Under"” ANZSEE Conference Blogs (Blog Post, December 2019) https:/www.neweconomy.org.au/anzsee/blogs/and-justice-forall/, for a fuller discussion of these schemes.

${ }^{44}$ See, for example, the New South Wales Biodiversity Offsets Scheme, enacted through the Biodiversity Conservation Act 2016 (NSW).

${ }^{45}$ For an excellent discussion on water pollution trading schemes, see J.H. Dales, 'Land Water and Ownership' (1968) 1(4) Canadian Journal of Economics 791.

${ }^{46}$ Christopher Wright and Daniel Nyberg, Climate change, capitalism, and corporations: processes of creative self-destruction, (Cambridge University Press, 2015) 41.

${ }^{47}$ Ibid 138.

${ }^{48}$ G. Brundtland, Report of the World Commission on Environment and Development: Our Common Future (1987). Available at: http://www.un-documents.net/our-commonfuture.pdf.

${ }^{49}$ Dryzek (n 6) 150-1. 
observed that, '[i]n essence, sustainable development is a process of change in which the exploitation of resources, the direction of investments, the orientation of technological development; and institutional change are all in harmony and enhance both current and future potential to meet human needs and aspirations'. ${ }^{50}$

The organisers of the 2012 United Nations Conference on Sustainable Development in Rio went further, stating, '[s]ustainable development emphasizes a holistic, equitable and far-sighted approach to decision making at all levels. It emphasizes not just strong economic performance but intragenerational and intergenerational equity. It rests on integration and a balanced consideration of economic and environmental goals and objectives in both public and private decision making. ${ }^{51}$ However, these definitions, whilst strong on vision, lack much in terms of how this works on the ground at a local, national and global level and have revealed vast spaces of contestation about priorities of human needs, and exactly what needs to be sustained. ${ }^{52}$

In some ways, sustainable development straddles the disconnects between all three problem-solving discourses above by validating the role of governments and experts, the role of citizens and the role of the market. This, however, is purely a launching pad for a complete reimagining of global, national and local structures to provide for humanity and the environment currently, and into the future. The discourse emphasises cooperation, progress and economic growth and maintains that 'economic growth, environmental protection, distributive justice, and long-term sustainability go together'. ${ }^{53}$

\footnotetext{
$\overline{50}$ Brundtland (n 48) 24.

${ }^{51}$ Cited in Dryzek (n 6) 147-8.

${ }^{52}$ Ibid 148. This does not negate the discourse however, because, as Dryzek observes, this is the fundamental orientation of democracy - the contestation of political concepts and it is in this space that numerous manifestations of sustainable development are both mediated and facilitated.

53 Ibid 160. However, despite the rhetoric of national governments and global organisations, it is hard to see where a complete adoption of sustainable development practices has occurred. Indeed, as the discourse has risen to prominence, the forces of
} 
It has been argued that there is a 'strong' and 'weak' approach to sustainable development. The 'strong' approach emphasises the earth's ecological integrity as a prerequisite for determining the boundaries of economic prosperity and development. The 'weak' approach, unsurprisingly pursued by governments and corporations, hold economic, social and environmental concerns as having equal importance. ${ }^{54}$ However, this is an uneasy balance to strike, given the prevailing political and social discourses of the $20^{\text {th }}$ and $21^{\text {st }}$ centuries.

In many ways, sustainable development is at odds with modernity's project of neoliberalism. Neoliberalism is derived from the discourses of liberalism which prioritise individual rights and entitlements over social and environmental responsibilities, as is evidenced by many of the predominant liberal thinkers, such as Locke, Blackstone and Bentham. ${ }^{55}$ Their philosophies effectively subordinated the environment to the needs, entitlements and aspirations of humans. Although they were $19^{\text {th }}$ century thinkers, their work, although tempered, still exerts a significant influence in contemporary times. As a result, it is hard to ignore the 'ever-widening gap between the notions of individual entitlement and the responsibility for the commons ${ }^{56}$ and the way it informs notions of sustainable development.

\subsection{The "Promethean" Discourse}

It would be errant to discuss environmental discourses without considering those that deny, or are at least deeply sceptical of, the prospect of long-term environmental harm. Dryzek has termed this discourse 'the Promethean response' after Prometheus, who stole fire

market capitalism have also increased. This bodes poorly for sustainable development unless it can be proved that its adoption will advance profits and economic growth.

${ }^{54}$ Klaus Bosselmann, 'A vulnerable environment: contextualising law with sustainability' (2011) 2(1) Journal of Human Rights and the Environment 45 ,54.

${ }^{55}$ Klaus Bosselmann, 'Property rights and sustainability: can they be reconciled?' in David P Grinlinton, David Grinlinton and Prue Taylor (eds), Property Rights and Sustainability: The Evolution of Property Rights to Meet Ecological Challenges (Brill, 2011) 23, 31.

${ }^{56}$ Bosselmann, above n 54, 52. 
from the Greek god, Zeus, thus increasing man's abilities to manipulate his environment. ${ }^{57}$

Prometheans view the earth from a mechanistic perspective, recognising its importance mostly in terms of markets, prices, energy, technology and people. ${ }^{58}$ It is, perhaps, the most anthropocentric ${ }^{59}$ of all the environmental discourses and deny any environmental agency. The earth is seen as 'inert and passive' ${ }^{60}$ and Prometheans take for granted a hierarchy dominated by humans. ${ }^{61}$

It is unsurprising that this discourse thrives alongside the discourses and implementation of industrialism and capitalism. ${ }^{62}$ The discourse relies on big-picture trends to validate their proposition that things are improving, so there is nothing or little to be concerned about. These trends may include evidence of increased life expectancy, increased resource prices, increased recreational areas and bigger food and resource yields than ever before. ${ }^{63}$

Ultimately, Prometheans are inclined to believe that the earth is.$^{64}$ This is reflected in the deeply capitalist approach of the Western worldview. Additionally, they are inclined to suggest that the ingenuity of humans will be able to solve any problems. ${ }^{65}$ The Promethean discourse has long been taken for granted. However, in recent times, with the increasing awareness of many environmental issues, cause has been created to examine this assumption.

\footnotetext{
${ }^{57}$ Dryzek (n 6) 52.

${ }^{58}$ Ibid 63.

${ }^{60}$ Dryzek (n 6) 60.

${ }^{61}$ Ibid 61.

${ }^{62}$ Ibid64.

${ }^{63}$ Ibid 63.

${ }^{64}$ Ibid 67.

${ }^{65}$ Ibid 69.
}

59 '[T]he planetary-scale subordination of nonhuman organisms that denies they have value in their own right.' (Helen Kopina, Haydn Washington, Bron Taylor, J Piccolo, 'Anthropocentrism: more than just a misunderstood problem' (2018) 31 (1) Journal of Agricultural \& Environmental Ethics 109, 115.) 
Dryzek's work provides a valuable study of contemporary prevailing environmental discourses that are deployed in seeking to address complex environmental issues. However, they are not the only discourses that have proved instrumental in engaging with the geography and challenges of the Murray-Darling Basin. Some further discourses will be explored in the next section, including the Indigenous practices that existed prior to 1788, and the impact of the Enlightenment on European thinking and practices that were transported to Australia at the time of European colonisation.

\section{History of Discourse and Law in the Murray-Darling Basin}

The Murray-Darling Basin has had a rich and complex history. Human civilisation has existed in the basin for at least 40,000 years. It is only in the last 200 years that significant damage and degradation has occurred to the river system. It is therefore apposite to consider the historical contexts of the discourses and laws that prevail in contemporary times, in order to more fully appreciate and understand them. This section firstly considers the role and practice of the Indigenous nations that lived in the Murray-Darling Basin prior to European colonisation in 1788. Secondly, the body of European discourse and laws existing prior to 1788 are explored, in order to grapple with the assumptions about water, property rights and the role of the environment that were imported and imposed when Europeans arrived in Australia. Thirdly, an overview of the history of laws concerning the Murray-Darling Basin, subsequent to 1788 , will be discussed. Finally, consideration will be directed to the international influences that have emerged since the latter half of the $20^{\text {th }}$ century and the role they have played in the governance of the river network.

\subsection{Indigenous Nations in the Murray-Darling Basin}

Indigenous understandings of the value and care of their environment are steeped in an intergenerational connectedness between people and their surroundings. This is conceived as 'a holistic entity that 
is not negotiable'. ${ }^{66}$ It is exemplified by the Ngarrindjeri nation, living at the mouth of the Murray River in South Australia, who believe that

The land and waters is a living body. We the Ngarrindjeri people are a part of its existence. The land and waters must be healthy for the Ngarrindjeri to be healthy. We say that if Yarluwar-Ruwe [Sea Country] dies, the waters die, our Ngartjis [totems] die, then the Ngarrindjeri will surely die. ${ }^{67}$

It is evident that many of the Indigenous nations in the basin were reliant on the river system for food, culture and their identity. In the lower Murray area, fish and shellfish accounted for about 40 per cent in Indigenous protein intake and was supplemented with other river plant harvest, such as cumbungi. ${ }^{68,}{ }^{69}$ The river supplied reeds for making baskets, an important cultural practice ${ }^{70}$ and featured in many Dreaming ${ }^{71}$ stories such as that of the giant Murray Cod, Pondi, 'whose lashings widened the ancestral Murray stream and transformed it into the current river, creating saltwater and freshwater fish from the pieces' ${ }^{72}$

Further north, in Brewarrina, massive fish-traps on the Darling River were witnessed by explorer, Thomas Mitchell; and were argued

\footnotetext{
${ }^{66}$ Jessica Weir, Lisa Strelein, \& Monica Morgan, 'Indigenous water rights within the Murray-Darling Basin’ (2003) 5(29) Indigenous Law Bulletin 17, 18.

${ }^{67}{ }^{68}$ Australian Government Department of the Environment and Energy. https://www. environment.gov.au/indigenous/publications/pubs/ngarrindjeri-scp-2006-1.pdf. 13, cited in Lynley A Wallis \& Alice C Gorman, 'A time for change? Indigenous heritage values and management practice in the Coorong and Lower Murray Lakes region, South Australia' (2010) 1 Australian Aboriginal Studies 57, 59.

${ }^{68}$ Chris Guest, Sharing the Water: One hundred years of River Murray politics (MurrayDarling Basin Authority, 2016) 4.

${ }^{69}$ Cumbungi is a native Australian bulrush plant.

${ }^{70}$ Lynley A Wallis \& Alice C Gorman, 'A time for change? Indigenous heritage values and management practice in the Coorong and Lower Murray Lakes region, South Australia' (2010) 1 Australian Aboriginal Studies 57, 64.

${ }^{71}$ Aboriginal traditions detailing the beginnings of life and the environment.

72 Ibid 63.
} 
to be one of the oldest surviving man-made structures. ${ }^{73}$ This, and many other examples demonstrate that Indigenous Australians were not simply passive users of rivers and streams within the Murray-Darling Basin. They were, rather, actively engaged with them in creating and sustaining life and identity. Consequently, the decline in river health over the last 200 years has had a disproportionate effect on Indigenous peoples, as the first peoples of the Murray-Darling basin, because it is inextricably linked to their culture, identity, and subsistence. ${ }^{74}$

Despite Indigenous nations clearly striking the balance between conservation and survival for more than 40, 000 years, it took a very short time for a profound disruption to that balance to take hold. In 1788, the British arrived in Sydney harbour with the intention of colonising Australia; a vast, perceived terra nullius $^{75}$ on which to impose their supposedly superior beliefs and practices. The reality, however, was that the introduction of European beliefs and practices were to have dire consequences for the Murray-Darling Basin.

\subsection{British Discourses in $\mathbf{1 7 8 8}$}

European and British discourses surrounding land and rivers were subject to significant challenge and development in the hundred years prior to the arrival of the First Fleet in Australia. In Europe, this was substantially due to the advent of the 'Enlightenment' or 'age of reason' that ushered in the age of modernity. In the resulting discourses that emerged from the Enlightenment, the environment was reduced to an entity completely separate from the human sphere. ${ }^{76}$ Specifically,

Environmental reductionism nurtures a mindset of total human dominance over, and relative independence from, nature, in which 'nature' becomes 'the other' and is constructed as inferior,

\footnotetext{
${ }^{73}$ Bruce Pascoe, Dark Emu: Black seeds, agriculture or accident? (Magabala Books, 2013) 53.

74 Jessica Weir, Lisa Strelein, \& Monica Morgan, 'Indigenous water rights within the Murray-Darling Basin’ (2003) 5(29) Indigenous Law Bulletin 17, 18.

75 (Latin) Land belonging to no-one.

${ }^{76}$ Bosselmnn (n 54) 46.
} 
functioning as little more than raw material for economictechnological progress. ${ }^{77}$

It was against this backdrop that British property law, having steadily developed since the invasion of William the Conqueror in 1066, was subjected to the gaze of philosophers and jurists, such as Locke, and Blackstone. John Locke (1632-1704) was concerned with individual entitlements that property afforded, and this was often at the expense of responsibilities to the common. ${ }^{78}$ His notion that property was rightly acquired through 'the mixing of labour' justified the premise that a man (women were afforded no such entitlements) could take possession of any 'unowned' property with which he has invested his labour, for his benefit. To Locke's way of thinking, 'each man has a right to the fruits of his labour because each has a right to that in which his workmanship is embodied'. ${ }^{79}$ At Common Law, a landowner was entitled to make whatever use he wanted of his property, provided that he did not infringe any of his neighbour's property rights. ${ }^{80}$ Australia, therefore provided a rich opportunity, in the eyes of the British, for anyone wishing to invest their labour.

William Blackstone (1723-1780) was also influential in $18^{\text {th }}$ century Britain. His Commentaries on the Laws of England ${ }^{81}$ accompanied the First Fleet on their arrival in Australia. He famously noted that

There is nothing which so generally strikes the imagination, and engages the affections of mankind, as the right of property; or that sole and despotic dominion which one man claims and exercises over the external things of the world, in total exclusion of the right of any other individual in the universe. ${ }^{82}$

\footnotetext{
${ }^{77}$ Ibid 48.

${ }^{78}$ Ibid 52.

${ }^{79}$ Eric Mack, John Locke (Bloomsbury Academic \& Professional, 2014) 59.

${ }^{80}$ Bates (n 1) 5.

81 Sprague, Blackstone's Commentaries, Abridged (Chicago: Callaghan and Co, $9^{\text {th }}$ ed. 1915).

${ }^{82}$ Ibid 105.
} 
Of course, the reality was that property entitlements were not universal. As already mentioned, women were excluded from the rights of owning property. The rights of property ownership were afforded only to those with the means of acquiring it, thus excluding the majority of the population living in poverty, indentured service, or imprisoned. Of course, this also included the convicts who were transported to Australia in 1788 and subsequent years, who were to provide the hard labour necessary for others to 'rightfully' acquire the land. Once convicts had served their term of imprisonment, some were offered land grants by the colonists, facilitated by British law. ${ }^{83}$

Another important consideration in British and European discourse was what came to be known as the doctrine of Terra Nullius, or 'land belonging to no one'. Although not clearly articulated until the $19^{\text {th }}$ century, it was inherent in conceptions of European colonisation, having gradually evolved from principles of natural law since the Roman Empire. ${ }^{84}$ This was closely tied to identifying legal systems of property ownership, measured against prevailing European formulations. It is argued that 'The cultural disposition that produced terra nullius, particularly attitudes to the exploitation of nature and the belief that property is created by use,

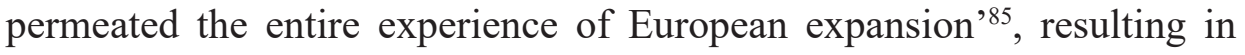
widespread 'acquisition' of land across the globe. A cursory glance by James Cook and Joseph Banks on the Endeavour in 1770, declared that no civilised system or law was evident, thus justifying a claim to the land and the imposition of British law upon colonisation. ${ }^{86}$ This, of course, was not the case; Indigenous Australians had a system of Indigenous law and engaged in many practices of utilising the land and waters. The doctrine

${ }^{83}$ Having 'acquired' the land under the doctrine of Terra Nullius, the British colonists could thence dispose of the land in any way it saw fit, subject to British law.

${ }^{84}$ See Andrew Fitzmaurice, 'The genealogy of Terra Nullius', (2007) 38(129) Australian Historical Studies, 1 for an interesting discussion on the evolution of the doctrine of Terra Nullius.

${ }^{85}$ Ibid 14.

${ }^{86}$ Catriona Cook, Robin Creyke, Robert Geddes, David Hamer, Laying Down the Law (LexisNexis Butterworths, $8^{\text {th }}$ ed. 2012) 39. 
of Terra Nullius was law in Australia until it was overturned in 1992 in Mabo, ${ }^{87}$ recognising surviving instances of Native Title.

There are many other philosophies and influences important in informing the attitudes of the British in 1788, for which space does not permit a fuller discussion. Britain was a nation at the pinnacle of their power, embodied in each of those responsible for overseeing the colonisation of Australia. ${ }^{88}$ This, combined with the doctrine of Terra Nullius; the notion of property as an individual entitlement to which men could make whatever use they wanted of it; along with the prevailing thinking of environmental reductionism proved devastating for the relatively pristine environments of Australia, and specifically for the Murray-Darling Basin.

\subsection{The Murray-Darling Basin 1788-1980}

Australia, in the years after 1788, was increasingly populated by separate British colonies in what now have become the States of Australia. In 1901, the Commonwealth of Australia was constituted, comprising a federation of six States and a new national government, each with their own legislative power. The limitations of each of the legislative powers, along with competing interests in the waters on the Murray-Darling Basin have been the site of fierce negotiation and contestation in the years since Federation.

British law in 1788 held that nobody 'owned' water. However, for those with a property adjoining a body of water, riparian rights were granted for a reasonable use of the water contained therein. ${ }^{89},{ }^{90}$ Victoria,

\footnotetext{
${ }^{87}$ Mabo v Queensland (No 2) (1992) 175 CLR 1

${ }^{88}$ See above n 74, 12 where Pascoe observes "The first colonists had their minds wrought by ideas of race and destiny; by the rumours heard as a child of the great British Empire. They were immersed in these stories as infants and later while marching in to school to 'Men of Harlech', standing to attention for 'God Save the King', and poring breathlessly over the stories of Horatio Nelson, the Christian Crusaders, King Arthur, Oliver Cromwell, and of course, Captain James Cook".

${ }^{89}$ Guest (n 68) 11.

${ }^{90}$ This made greater sense in a British context where regular rainfall and naturally fertile soils prevailed, however was not a fit for Australia's harsher environment, particularly in
} 
interestingly, was the first jurisdiction in the world to annex water rights as state property in $1886 .{ }^{91}$ This is important, because in Australia, water was a much scarcer resource than in Britain, and the need to regulate how it was used became a prime concern.

However, there were vastly competing and even irreconcilable economic interests between the States by the time of Federation when it came to the Murray River. The river delineates the border between New South Wales (NSW) and Victoria but is wholly within NSW. Both NSW and Victoria's interests were in extracting water for irrigation purposes. Water conservation had a very different meaning at that time, in that water not used was ultimately wasted. Water left in the river was considered as a 'flagrant injustice' and so the prevailing discourses endorsed the notion of 'irrigating the Murray dry'. ${ }^{92}$ South Australia (SA), west of Victoria and NSW, had as its main interest the supply of water for its population, and navigation. Paddle-steamers and barges provided a vital link for communication and supply for many along the river from South Australia. The gold rush that began in 1851 had provided additional opportunities for the river craft as they supplied food and equipment to new communities that had sprung up. ${ }^{93}$ Clearly, Victoria and NSW's interests in removing water from the river were at odds with SA's interest in having water for navigation and supply for its population. This was played out with the ever-present spectre of drought to be additionally mediated.

The first agreement between the three States about the management of the river, including entitlements to and the use of waters from the Murray River was signed at Corowa in 1902, however, it was not until 1914 that the River Murray Waters Agreement was signed and 1917 that the River Murray Commission was established. ${ }^{94}$ The agreement and subsequent amendments were ratified through each of the legislatures of

\footnotetext{
times of drought.

${ }^{91}$ Guest (n 68) 11.

92 Ibid 23.

${ }^{93}$ Ibid 8.

${ }^{94}$ Ibid vi.
} 
NSW, Victoria and SA as well as the Commonwealth and remained in force until 2007 when it was replaced by the Water Act 2007 (Cth).

The main focus in the first 65 years of the agreement was on engineering projects which saw construction of dams, locks and weirs. This began in the 1920's with the construction of the Hume Dam in the upper Murray and a storage facility at Lake Victoria. It concluded in 1979 with the completion of Dartmouth Dam. During this time, the Menindee Lakes storage facility on the Darling River was also constructed.

\subsection{The Emergence of Environmental Law in Australia and the Influence of International Environmental Law}

Prior to the $20^{\text {th }}$ century, any laws concerning the environment were ultimately enacted to order human activities and relations within society. ${ }^{95}$ In Australia, the first environmental law was enacted in the 1940's. ${ }^{96}$ In the latter half of the $20^{\text {th }}$ century, laws concerning pollution began to be developed. ${ }^{97}$ In the ensuing years, and as a result of continuing environmental decline, a greater emphasis has been place on wider environmental concerns which has broadened the scope of the importance of the environment not only for the benefit of human consumption, but for the continued existence of the environment itself. ${ }^{98}$ This is especially

\footnotetext{
95 These included the torts of trespass and nuisance where the effects of environmental harm caused by one person to another could find a remedy. Additionally, there was also legal right to challenge the lawfulness of government decision making regarding environmental issues. See Bates (n 1) 3-7 for a fuller discussion.

96 Brian J Preston, 'The Australian Experience on Environmental Law' (2018) Environmental and Planning Law Journal 35(6) 637, 638. Preston highlights the Local Government (Town and Country Planning) Amendment Act 1945 (NSW) which was enacted to control the rate and method of post-war development for 'the improvement of community life and the environment in which our people live' (Citing the second reading speech for the bill).

${ }^{97}$ In NSW, these included the Clean Air Act 1961 (NSW) and the Clean Water Act 1970 (NSW).

${ }^{98}$ See, for example, National Parks and Wildlife Act 1974 (NSW); and the Biodiversity Conservation Act 2016 (NSW). At the federal level, the Environment Protection and Biodiversity Conservation Act 1999 (Cth) demonstrates a greater emphasis on environmental issues.
} 
important in how the laws concerning water use in the Murray-Darling Basin have developed, particularly in the past 40 years.

An important principle in both State and Federal environmental laws is that of Ecologically Sustainable Development (ESD). This is derived from the discourse of sustainable development discussed above, and was adopted subsequent to the United Nations Conference on Environment and Development held in Rio de Janeiro in 1992. The Australian Government defines ESD as 'development which aims to meet the needs of Australians today, while conserving our ecosystems for the benefit of future generations'. ${ }^{99}$ ESD does not only concern itself with the environment. There is a 'triple bottom line' approach of managing economic, social and environmental outcomes. ${ }^{100}$ ESD considerations have become fundamental in environmental management, both through legislation and decision making. ${ }^{101}$

Internationally, it is not only the Rio Convention which informs Australian approaches to environmental law. Since the conclusion of World War II, and the establishment of the United Nations, the emergence of international influences has permeated many aspects of national policy and practice. With respect to the Murray-Darling Basin, there are a number of treaties that are important in the practical outworking of basin management. They include, Ramsar Convention on Wetlands of International Importance; ${ }^{102}$ UN Convention on Biological Diversity; ${ }^{103}$

\footnotetext{
99 'National Strategy for Ecologically Sustainable Development - Part 1 Introduction' Australian Government: Department of the Environment and Energy (Webpage). http://www.environment.gov.au/about-us/esd/publications/national-esd-strategypart1\#WIESD.

${ }^{100}$ See Tim Bonyhady, 'Putting the Environment First?' (2012) 29(4) Environmental and Planning Law Journal 316, 324.

${ }^{101}$ Bates (n 1) 178.

${ }^{102}$ Convention on Wetlands of International Importance Especially as Waterfowl Habitat, opened for signature $2^{\text {nd }}$ February 1971, 996 UNTS 245 (entered into force $21^{\text {st }}$ December 1975).

${ }^{103}$ Convention on Biological Diversity, opened for signature $5^{\text {th }}$ June 1992,1760 UNTS 79 (entered into force $29^{\text {th }}$ December 1993).
} 
UN Convention to Combat Desertification; ${ }^{104}$ The Bonn Convention; ${ }^{105}$ Bilateral Migratory Bird Agreements; ${ }^{106}$ and UN Climate Change Convention. ${ }^{107,108}$

\subsection{The Expanding Role of the Commonwealth}

During the latter decades of the $20^{\text {th }}$ century, it became obvious that the Murray River and its environment had begun to suffer significantly. There was substantial concern about salinity from the 1960's which were largely attributed to the irrigation activities. ${ }^{109}$ This was exacerbated in years of drought. ${ }^{110}$ In 1980, the Murray River mouth closed at Goolwa for ten months due to lack of flow. ${ }^{111}$ As these and other environmental issues developed, the focus of governance began to move away from engineering expertise, and gradually towards the management of environmental issues such as water, land and wider environmental quality. ${ }^{112}$

${ }^{104}$ United Nations Convention to Combat Desertification in Countries Experiencing Serious Drought and/or Desertification, Particularly in Africa, opened for signature $17^{\text {th }}$ June 1994, 1954 UNTS 3 (entered into force 26 ${ }^{\text {th }}$ December 1996).

${ }^{105}$ Convention on the Conservation of Migratory Species of Wild Animals, opened for signature $23^{\text {rd }}$ June 1979, 1651 UNTS 333 (entered into force $1^{\text {st }}$ November 1983).

106 These include Agreement Between the Government of Australia and the Government of Japan for the Protection of Migratory Birds and Birds in Danger of Extinction and Their Environment, Australia - Japan, [1981] ATS 6 (entered into force $30^{\text {th }}$ April 1981); Agreement between the Government of Australia and the Government of the People's Republic of China for the Protection of Migratory Birds and their Environment, Australia - China, [1988] ATS 22 (entered into force $1^{\text {st }}$ September 1986); and Agreement Between the Government of Australia and the Government of the Republic Of Korea on the Protection of Migratory Birds, Australia - South Korea, [2007] ATS 24 (entered into force $13^{\text {th }}$ July 2007).

${ }^{107}$ United Nations Framework Convention on Climate Change, opened for signature $9^{\text {th }}$ May 1992, 1771 UNTS 107 (entered into force 21 ${ }^{\text {st }}$ March 1994).

${ }^{108}$ See Guest (n 68) 99.

${ }^{109}$ Ibid 115.

${ }^{110}$ Ibid.

${ }^{111}$ Ibid 124.

${ }^{112}$ Ibid 132. 
The role of the Commonwealth in the early $20^{\text {th }}$ century was limited, partly due to Constitutional constraints. The fledgling Commonwealth was wary of overstepping their Constitutional powers. On one hand, they had the power to legislate for navigation with respect to trade and commerce between the States, ${ }^{113}$ however, they were not permitted to abridge the States of reasonable use of river water for conservation or irrigation. ${ }^{114}$ By primarily using the head of power for navigation, the Commonwealth made a contribution to ongoing development of the existing agreement, mostly in terms of funding. ${ }^{115}$ By the end of the $20^{\text {th }}$ century, the conflicting State interests in the Murray-Darling waters had not abated, and finding a workable solution to the environmental issues and continual supply of water in the basin proved increasingly elusive.

During the latter part of the $20^{\text {th }}$ century, the Commonwealth had substantially increased its legislative and political influence with regards to environmental issues. The most notable example was the Tasmanian Dams Case, ${ }^{116}$ where the High Court held that the Commonwealth had correctly used the External Affairs power and the Corporations power in the Constitution to prevent the construction of a hydro-electric dam on the Gordon River in Tasmania. This demonstrated that the Commonwealth had much wider powers than previously believed. ${ }^{117}$ In the $21^{\text {st }}$ century, the High Court has upheld the Commonwealth's ability to rely on a great number of Constitutional powers in order to legislate for the environment. ${ }^{118}$

By the 1990's, under the Hawke-Keating Labor governments, a new era of co-operative federalism ${ }^{119}$ emerged in tandem with microeconomic reforms which was to have important ramifications in the

\footnotetext{
${ }^{113}$ Commonwealth of Australia Constitution Act 1901 (Cth), s 98.

${ }^{114} \mathrm{Ibid}, 100$.

${ }^{115}$ Guest (n 68) 21.

${ }^{116}$ Commonwealth v Tasmania (1983) 158 CLR 1.

${ }^{117}$ Bates (n 1) 96-7.

${ }^{118}$ Ibid 91. These heads of power include: Trade and Commerce; Corporations; External Affairs; Finance and Taxation; 'People of any Race'; Quarantine; and Fisheries.

${ }^{119}$ A cooperative and collaborative approach between the Commonwealth and the States to manage multi-level responsibilities and policy.
} 
management of the Murray-Darling Basin. ${ }^{120}$ One of the first initiatives was to establish the Council of Australian Governments (COAG) in 1993, comprising the premiers and chief ministers of the Australian States and Territories. ${ }^{121}$ An early consideration for COAG was to address sustainable reform of the water industry, which included the waters of the Murray-Darling Basin, with a view to maximise economic efficiency of the resource. ${ }^{122}$ One of the first actions was to impose a 'cap' on surface water diversions to prevent a worsening of conditions for both irrigators and the environment. ${ }^{123}$ Additionally, water rights were separated from rights to land, thus enabling the trading of water on the open market. ${ }^{124}$ In 2004, the National Water Commission was established as a regulatory and planning agency to manage surface and groundwater in order to 'optimise economic, social and environmental outcomes'. ${ }^{125}$

By 2007, whilst in the grip of the 'millennium drought', there was a growing recognition that the existing management practices for the Basin had reached their 'use-by date' and new approaches and strategies were required. ${ }^{126}$ It was against this backdrop that the Commonwealth enacted the Water Act 2007 (Cth), relying on its external affairs power, particularly in light of its obligations to the Ramsar Convention on Wetlands of International Importance and the Convention on Biological Diversity ${ }^{127}$. Subsequently, in 2008, the Basin States enacted a limited referral of powers to the Commonwealth with respect to the management of the Murray-Darling Basin, enabling the Commonwealth to more broadly legislate in this area. This resulted in an amendment to the Water Act in that year and the establishment of a new management body, the MurrayDarling Basin Authority. The Authority was responsible for creating a

\footnotetext{
${ }^{120}$ Bates (n 1) 497.

${ }^{121}$ Guest (n 68) 160.

122 Ibid 161.

${ }^{123}$ Barry T Hart, 'The Australian Murray-Darling Basin Plan: Factors leading to its successful development' (2016) 16 Ecohydrology \& Hydrobiology 229, 231.

${ }^{124}$ Bates (n 1) 497.

${ }^{125}$ Ibid. The National Water Commission was abolished in 2015.

126 Ibid.

${ }^{127}$ Guest (n 68) 206.
} 
Basin management plan which was approved in November 2012 by the Commonwealth parliament. ${ }^{128}$ This has been primarily rolled out between 2013-19, although some aspects will continue to be implemented over the next decade. ${ }^{129}$

The waters of the Murray-Darling Basin have been adversely affected by the way it has been engaged since the British arrived in 1788 . The Indigenous Nations living in the Basin prior to colonisation had a symbiotic relationship to the rivers, and saw a responsibility to care for their environment as part of their spirituality and practices, where both needed the other to survive. However, the health of the rivers shifted substantially since 1788, and significantly in the last century.

The growth of environmental law has sought to address these issues, but it is against the legacy and scars that the last 100 years have left. The most significant development is the expanding role of the Commonwealth in seeking to manage the environmental aspects of the Murray-Darling Basin. This is ostensibly with the cooperation of the States under the mantra of cooperative federalism, an approach that has seen significant reform in the environmental management approach to what are extremely complex issues. Australia has additionally been required to account for an increasing body of international law in the form of conventions and agreements that require Australia to implement policies and practices designed to protect numerous aspects of the environment. These considerations have resulted in a new body of Commonwealth law governing the method and structure of water management in the Basin.

\section{The Laws of the Murray-Darling Basin}

The $20^{\text {th }}$ century saw a number of different discursive approaches to natural resource management in general, and the Murray-Darling Basin in particular. Central to the development of the different approaches were the prevailing worldviews operating at various times, because no approach operates in a vacuum devoid of all else but the focus of the

\footnotetext{
${ }^{128}$ Basin Plan 2012 (Cth).

${ }^{129}$ Hart (n 124) 232.
} 
management need. This is particularly important when considering the profound impact that the Enlightenment has had on how the environment is perceived in relation to human affairs. This section will examine the prevailing environmental discourses, and their effects, between 1900 and 1990 before moving on to the rise of a sustainable development discourse from 1990 until the present day.

\subsection{The Period Between 1900-1990: Administrative Rationalism}

The focus of environmental concern in what was to become known as the Murray-Darling Basin through the $19^{\text {th }}$ and most of the $20^{\text {th }}$ century was meeting the needs of a growing European population subsequent to 1788. Central to this was the need for water to sustain the agricultural practices imported from Britain, where water was far more abundant and regularly replenished; and sustain the growth of communities that developed along the rivers. ${ }^{130}$ In the ensuing years, the waters of the Murray-Darling Basin have been either extracted or engaged to develop industries such as agriculture, mining, tourism and leisure, hydroelectricity generation, and commercial fishing, amongst others. ${ }^{131}$

The perception that water in the Basin was a resource that had to be managed resulted in the emergence of a discourse focused on problem solving. In this case, it was predominantly apparent that the discourse of administrative rationalism was deployed. This discourse was perceivable as early as 1912, where the Inter-State Commission, formed in response to the competing interests in the river, was observed by former Prime Minister Alfred Deakin as 'simply a body of experts, called upon, after personal investigation of a searching and scientific character, to lay before the states interested in all the facts'. ${ }^{132}$

The creation of the River Murray Commission in 1917 consolidated this discursive approach. It largely drew on the expertise of engineers

\footnotetext{
${ }^{130}$ John Scanlon, 'A hundred years of negotiations with no end in sight: Where is the Murray-Darling Basin Initiative leading us?' (2006) 23(5) Environmental and Planning Law Journal 386, 387.

131 Ibid.

${ }^{132}$ Guest (n 68) 50.
} 
to manage the development and works on the Murray River. This was manifested in the construction of dams, locks and weirs to manage the flow of the river and maximise the efficiency of water extraction.

As environmental issues rose to the fore from the 1960's, environmental experts were sought to provide solutions to the health of the river. It was during this time that the rise of international concern for the environment was starting to occur. This resulted in a very gradual shift toward a new approach to environmental management.

\subsection{Ecologically Sustainable Development (ESD)}

The 1990's saw a substantial shift in the application of environmental discourses. The release of the Our Common Future Report $^{133}$ in 1987 provided a catalyst for the rise of the discourse of sustainable development. This was reinforced by the United Nations Conference on Environment and Development held in 1992, as discussed above. The resulting conventions, particularly the Convention on Biological Diversity ${ }^{134}$, to which Australia is a signatory, embodied the principles of sustainable development inherent in managing natural resources. In Australia, this has resulted in the National Strategy for Ecologically Sustainable Development ${ }^{135}$ and later, the National Strategy for the Conservation of Australia's Biological Diversity. ${ }^{136}$ Since then, the discourse and principles of ESD have become fundamental in both federal and state considerations of policy and legislation concerning the environment. ${ }^{137}$

\footnotetext{
${ }^{133}$ Brundtland (n 48).

${ }^{134}$ Convention on Biological Diversity, opened for signature $5^{\text {th }}$ June 1992, 1760 UNTS 79 (entered into force 29th December 1993).

135 Australian Government: Department of the Environment and Energy (Webpage). https://www.environment.gov.au/about-us/esd/publications/national-esd-strategy.

${ }^{136}$ Australian Government: Department of the Environment (Webpage). https://www. environment.gov.au/archive/biodiversity/publications/strategy/index.html.

${ }^{137}$ Bates (n 1) 177.
} 


\subsubsection{From Discourse to Reality}

In the Murray-Darling Basin, one of the first moves toward protecting the over-exploitation of waters in the rivers came in 1997 when the Commonwealth placed a 'cap' on water extraction. ${ }^{138}$ The 'cap' sought to limit extraction to the 1993-4 level. ${ }^{139}$ This proved ultimately unsuccessful in tempering the continued effects of ecological degradation, despite the recognition that the Basin required 'environmental water' to survive. ${ }^{140}$ The National Water Initiative built on this first step in 2004, and was designed to implement a plan where water allocation was delivered in line with sustainable use. ${ }^{141}$ This was accompanied by the Living Murray Intergovernmental Agreement, which set targets for investment and water recovery within the Basin. ${ }^{142}$

Three years later, the enactment of the Water Act 2007 (Cth) promised a comprehensive approach to the complex issues that the Basin experienced. It is clear, however, that regard for the environment per se was not the overriding objective of the Water Act. ${ }^{143}$ The place and priority of the environmental protection in ESD generally is highly contested. The second reading speech for the bill, delivered by the Minister for the Environment and Water Resources, Malcolm Turnbull, made it clear that concern for the environment was only one, and obviously not the first, consideration when it came to protecting interests in the Basin,

The reforms in the bill are needed to meet the future challenges facing water management in the Murray-Darling Basin. We need

\footnotetext{
${ }^{138}$ Ibid 503.

${ }^{139}$ Ibid.

${ }^{140}$ Ibid.

${ }^{141}$ Bonyhady (n 101) 321.

${ }^{142}$ Scanlon (n 131) 394.

${ }^{143}$ The long title of the Act denotes it as,

An Act to make provision for the management of the water resources of the Murray-Darling Basin, and to make provision for other matters of national interest in relation to water and water information, and for related purposes.
} 
these reforms to ensure the viability of our water dependent industries, to ensure healthy and vibrant communities and to ensure the sustainability of the basin's natural environment. ${ }^{144}$

Whilst it is clear that ESD was the explicit discourse touted by politicians and bureaucrats as the way to restore ecological integrity to the Murray-Darling Basin, it has become apparent that, in fact, the mechanisms and regulations deployed to achieve this outcome prioritise the discourse of economic rationalism.

\subsubsection{ESD in the Water Act}

Ecologically sustainable development has been adopted within the Australian environmental law framework, however exactly what it means, and entails, is 'notoriously difficult to grasp'. ${ }^{145}$ This elusiveness has provided a foothold for competing environmental discourses to fill the gaps, as it were.

The Water Act defines the principles of economically sustainable development applicable in the Murray-Darling Basin. They include the importance of the triple-bottom line in decision making; the precautionary principle; the principle of intergenerational equity; the principle that biodiversity and ecological integrity should be fundamental in decision making; and that improved market mechanisms be promoted. ${ }^{146}$

Explicit in these principles is a regard to environmental considerations in decision making, and both the Murray-Darling Basin Authority and the Minister must take these principles into account when developing policy and making decisions. ${ }^{147}$ Additionally, the development of the Murray-Darling Basin Plan must implement international agreements, and be aware that the use of water resources is inherent

${ }^{144}$ Commonwealth, Parliamentary Debates, House of Representatives, 14 August 2007, 111, (Malcolm Turnbull, Minister for the Environment and Water Resources).

${ }^{145}$ Bates (n 1) 196.

${ }^{146}$ Water Act 2007 (Cth) s 4(2).

${ }^{147}$ Ibid 4 (a). 
in ongoing considerations regarding ecosystems, natural habitats, conservation and biodiversity. ${ }^{148}$

The Act and the Management Plan seek to establish a scheme of planned environmental water. This means identifying what ecological areas need water, and how much of it, and implementing strategies of ensuring that supply. ${ }^{149}$ This effectively limits the amount of water that can be taken from the Basin to what is mandated as the Environmentally Sustainable Level of Take' (ESLT). ${ }^{150}$

The mechanism deployed for managing the waters of the MurrayDarling Basin is the marketisation of water, where rights for water extraction are managed within the ESLT framework and traded on the open market. ${ }^{151}$ The discourse of ESD, in this case, appears to have privileged the economic pillar, which has resulted in the weakening of ESD and the strengthening of the discourse of economic rationalism

\subsection{The Ongoing Legacy of 18th \& 19th century European Discourse}

The discourses of human's relationship to their environment that were brought to Australia in 1788 are still entrenched in much of Australia's social and institutional dispositions. These include the 'rational' separation (and ensuing dominance) of humanity from its broader environment and the privileging of human needs and aspirations over wider environmental considerations. Although practices of sustainability have existed since ancient times, and were clearly evident in Indigenous practices in Australia prior to 1788, the anthropocentric advent of industrialisation, colonialism, and their associated technologies have marginalised many sustainability practices and accelerated the engagement of natural resources and the perceived need of them to provide economic and social growth. ${ }^{152}$

\footnotetext{
${ }^{148}$ Ibid 21 (1) - (3).

149 Bates (n 1) 505.

${ }^{150}$ See Water Act 2007 (Cth) ss 4, 23(1), 23A(3)(b).

151 Ibid 10.

${ }^{152}$ Ben Boer, 'Implementing Sustainability' (1992) 14 Delhi Law Review 1, 5.
} 
Environmental law in Australia has developed in the crucible of these discourses and is indicative of the reductionism that exists in environmental law; that is, that rather than humans and their environment being interconnected, humans are considered as independent actors to the environment. ${ }^{153}$ The law has both enabled and constrained the development of strategies and discourses that have been deployed in the last 120 years and prior to managing the environment of the MurrayDarling Basin.

This is evident in the way that ESD has been contextualized in the Water Act ${ }^{154}$ and the Murray-Darling Basin Plan. ${ }^{155}$ Even if equal weighting were given to each of the three pillars, human-centric considerations of economic prosperity and social wellbeing would outweigh the environmental pillar. Additionally, the deployment of an economic mechanism to implement the legislation perhaps belies the true priority of this policy, by demonstrating that the priority of the economy is at least as, if not more, important than the health of the environment.

In Australia, the discourse of an ever-growing economy being in the interest of every Australian underpins much of the vision-casting and policy of the major political parties. In the Murray-Darling Basin, the issue was how to manage the environmental challenges of the various rivers. Specifically, the existing over-exploitation of water from the rivers for agricultural and industrial purposes needed to be addressed, because without enough water sanctioned purely for the health of the rivers, it was recognized that the river system would no longer be viable.

While there may have been many ways to approach the issue of restoring a healthy river system, of which discussion is beyond the scope of this paper, the mechanism that was deployed by the Water Act to address the over-extraction of water and return environmental health to sustainable levels was to marketise water allocations. This then required

${ }^{153}$ Klaus Bosselmann, 'Losing the forest for the trees: Environmental reductionism in the law’ (2010) 2(8) Sustainability 2424, 2431.

${ }^{154}$ Water Act 2007 (Cth).

${ }^{155}$ Basin Plan 2012 (Cth). 
the creation of a trading scheme in which water entitlements could be bought and sold.

It has now been twelve years since the Water Act was enacted and seven years since the introduction of the Basin Plan. There are a growing number of dissenting voices concerning the effectiveness of the Basin Plan. The South Australian Royal Commission into the Murray-Darling Basin delivered a scathing report into the effectiveness and management of the Basin Plan. Specifically, it found that the environmentally sustainable level of take (ESLT) was unlawfully calculated by using a triple bottom line approach, inconsistent with s 23 of the Water Act, ${ }^{156}$ which required only a consideration for the environment. Additionally, it accused the Murray-Darling Basin Authority (MDBA) of completely ignoring climate change projections, and favoring 'politics over science' in doing so. ${ }^{157}$ This has led to the Royal Commission's conclusion that 'the MDBA has shown itself to be unwilling or incapable of acting lawfully'. ${ }^{158}$

Other voices of dissent highlight the dangers of allocating millions of dollars of tax-payer money to the construction of irrigation infrastructure, including dams, ${ }^{159}$ a scheme labelled as 'pink batts for farmers'. ${ }^{160}$ Others criticise the tactics used by big corporations and investment banks who are buying water not for their own use, but in order to solely make a profit within the market. ${ }^{161}$ The marketisation of water, it could be argued, effectively contributes to the prioritisation in the

\footnotetext{
${ }^{156}$ Murray-Darling Basin Royal Commission (n 6) 54.

${ }^{157}$ Ibid.

${ }^{158}$ Ibid 55.
}

159 Sean Rubinsztein-Dunlop, Mary Fallon, Lucy Carter and Michael Slezak, 'How taxpayers are funding a huge corporate expansion in the Murray-Darling Basin' $A B C$ News, Four Corners (Webpage, $8^{\text {th }}$ July 2019). https://www.abc.net.au/news/2019-07-08/ taxpayers-helping-fund-murray-darling-basin-expansion/11279468.

160 'Cash Splash', Four Corners (Australian Broadcasting Corporation, 2019) 00:37 00:42. https://iview.abc.net.au/show/four-corners/series/2019/video/NC1903H022S00. 'Pink Batts' refers to the failed scheme implemented by the Rudd Government in 2009 as part of a stimulus program to mitigate the effect of the Global Financial Crisis on the Australian economy.

${ }^{161}$ Ibid 03:25 - 03:57. 
marketplace of generating profit rather than concern for environmental health because it is seemingly left to the bureaucrats to manage the environment.

The rivers themselves, are also showing signs of increased strain. This was highlighted at the end of 2018, when up to a million fish were found dead in the Darling River at Menindee, the suspected result of a blue-green algal bloom. ${ }^{162}$ Further south, The Barmah Choke, the narrowest part of the Murray River in the internationally significant wetland of the Barmah-Millewa Forest was undergoing a very different catastrophe. The demand for water by irrigators downstream of the Choke during drought, resulted in artificially increased flows in order to supply that demand. This has caused the collapse of the riverbanks, thus currently reducing the carrying capacity of the waterway and causing flooding in the area. ${ }^{163}$

The enactment of the Water Act 2007 (Cth) was heralded as the solution for restoring ecological health to the Murray-Darling Basin. However, it is evident in the outworking of the legislation that a multiplicity of environmental discourses have been vying for supremacy, arguably with the ecological integrity of the environment left in their wake. These have included the continued notion of the separation and dominance of humans over their environment; the centrality in society and upheld in law of anthropocentric rights and entitlements, particularly regarding private property; and the pivotal role that economic markets play in Australia. The discourse of ecologically sustainable development, whilst touted as the basis for the legislation, appears to have given way to the discourse of economic rationalism.

${ }^{162}$ Rhys Carman and Sara Tomevska, 'A million dead fish in 'distressing' outback algal bloom at Minindee', ABC News (Webpage, $15^{\text {th }}$ January 2019). https://www.abc.net.au/ news/2019-01-08/second-fish-kill-in-darling-river-at-menindee/10696632.

${ }^{163}$ Clint Jasper, 'Drought reveals fault lines in Murray-Darling Basin strategy with dead fish, flooded forests and dying red river gums' $A B C$ News, Landline (Webpage, $30^{\text {th }}$ June 2019). https://www.abc.net.au/news/rural/2019-06-30/barmah-choke-struggling-withwater-flow-adds-to-mdba-woes/11251438. 


\section{Conclusion}

The Murray-Darling Basin is an environment that has always been subject to the natural challenges of drought and flood. Still, in the last 120 years human activity along the rivers have irretrievably altered the nature and quality of the Basin environment.

The Basin has been subject to many environmental discourses over many thousands of years. Indigenous Australians, prior to 1788, practiced discourses that valued the symbiotic relationship between them and their environment. This was profoundly disrupted after European colonisation, when the prevailing European discourses, that were deployed by the settlers, had separated humans from their environment and elevated them to a position of mastery over a subsequently subordinate environment. This was particularly manifested in the anthropocentric right to own property and develop economic interests based on ownership.

In the 20th Century, with the growing recognition of environmental issues, a number of discourses have been either crystallised or developed in response to these concerns. Dryzek refers to problem-solving discourses of administrative rationalism, democratic pragmatism, and economic rationalism; discourses of sustainable development; and the 'Promethean' discourse, which denies any enduring damage by humans to their environment. ${ }^{164}$ Of these, it is the discourses of sustainable development and economic rationalism that are most prevalent in the current management of the Basin. However, even though the principles of ecologically sustainable development are articulated as underpinning the Water Act 2007 (Cth), it is evident that the Basin is ultimately regulated through the economic rationalism discourse. This is achieved through the strategy of marketising water rights and trading them on the open market.

The discourse of ecologically sustainable development (ESD) is, in this case, subservient to the discourse of economic rationalism. This is evident in the prioritisation of economic interests over long-term concern for the environment. The use of a triple-bottom line approach has prioritised economic interests to such an extent that ESD is arguably

${ }^{164}$ Dryzek (n 6). 
unrecognisable and the integrity of ecological and biological diversity is at significant risk.

The South Australian Royal Commission ${ }^{165}$ highlighted many issues that demonstrate that the current approach is not effective. Other voices are calling for a Federal Royal Commission. ${ }^{166}$ It is evident that the future of the Murray-Darling Basin is dependent on a willingness to reconceptualise why environmental interests are important, and how humans and the environment can better live and thrive together.

This paper has sought to identify the prevailing discourses evident in the management of the Murray-Darling Basin over the past two centuries. It is limited, however, because it has not addressed specifically how these discourses were deployed, or engaged in a comprehensive evaluation as to their effectiveness. Further, whilst a broad discussion was undertaken as to the influence of non-indigenous discourses, it did not take into account the full scope of applicable discourses that may be brought to bear when considering the management of the Basin. Finally, there is much more to be said about Indigenous approaches to environmental management that preserved and nurtured the environment for tens of thousands of years; that this paper was not able to more fully consider them in the context of the Murray-Darling Basin environment is another regrettable limitation.

\section{References}

AGREEMENT Between the Government of Australia and the Government of Japan for the Protection of Migratory Birds and Birds in Danger of Extinction and Their Environment, Australia - Japan, [1981] ATS 6, entered into force $30^{\text {th }}$ April 1981.

AGREEMENT between the Government of Australia and the Government of the People's Republic of China for the Protection of Migratory Birds and their Environment, Australia - China, [1988] ATS 22, entered into force $1^{\text {st }}$ September 1986.

${ }^{165}$ Murray-Darling Basin Royal Commission, (Report 2019)

166 Bates (n 1) 507. 
AGREEMENT Between the Government of Australia and the Government of the Republic Of Korea on the Protection of Migratory Birds, Australia - South Korea, [2007] ATS 24, entered into force $13^{\text {th }}$ July 2007.

AUSTRALIAN Government: Department of the Environment and Energy, 'National Strategy for Ecologically Sustainable Development' (Webpage). https://www.environment.gov.au/about-us/esd/publications/ national-esd-strategy.

AUSTRALIAN Government: Department of the Environment, 'National Strategy for the Conservation of Australia's Biological Diversity' (Webpage): https://www.environment.gov.au/archive/biodiversity/ publications/strategy/index.html.

AUSTRALIAN Government: Murray-Darling Basin Authority, 'Discover the Basin', (Webpage). https://www.mdba.gov.au/discover-basin.

BASIN PLAN 2012. (Cth).

BATES, Gerry. Environmental Law in Australia. Lexis Nexis Butterworths, $10^{\text {th }}$ ed. 2019.

BIODIVERSITY CONSERVATION ACT, 2016. (NSW).

BOER, Ben. Implementing Sustainability, 14 Delhi Law Review 1. 1992.

BONYHADY, Tim. Putting the Environment First? Environmental and Planning Law Journal, 29, (4), 316, 2012.

BOSSELMANN, Klaus. A vulnerable environment: contextualising law with sustainability. Journal of Human Rights and the Environment, 45, 2 (1), 2011.

BOSSELMANN, Klaus. Losing the forest for the trees: Environmental reductionism in the law. Sustainability, 2 (8), 2.424, 2010.

BOSSELMANN, Klaus. Property rights and sustainability: can they be reconciled? In: GRINLINTON, David P.; TAYLOR, Prue (ed.). Property Rights and Sustainability: The Evolution of Property Rights to Meet Ecological Challenges, Brill, 2011. 23. 
BRUNDTLAND, G. Report of the World Commission on Environment and Development: Our Common Future (1987). Available at: http://www. un-documents.net/our-common-future.pdf.

CARMAN, Rhys; TOMEVSKA, Sara. A million dead fish in 'distressing' outback algal bloom at Minindee'. ABC News, Webpage, 15th January 2019. https://www.abc.net.au/news/2019-01-08/secondfish-kill-in-darling-river-at-menindee/10696632.

CLEAN AIR ACT, 1961. (NSW).

CLEAN AIR ACT, 1961. (NSW).

CLEAN WATER ACT, 1970. (NSW).

CLINT JASPER. Drought reveals fault lines in Murray-Darling Basin strategy with dead fish, flooded forests and dying red river gums' ABC News, Landline, Webpage, 30th June 2019. https://www.abc.net.au/news/ rural/2019-06-30/barmah-choke-struggling-with-water-flow-adds-tomdba-woes/11251438.

COMMONWEALTH OF AUSTRALIA CONSTITUTION ACT, 1901. (Cth).

COMMONWEALTH v Tasmania, 1983. 158 CLR 1.

CONVENTION on Biological Diversity, opened for signature $5^{\text {th }}$ June 1992, 1760 UNTS 79, entered into force 29 $9^{\text {th }}$ December 1993.

CONVENTION on the Conservation of Migratory Species of Wild Animals, opened for signature $23^{\text {rd }}$ June 1979, 1651 UNTS 333, entered into force $1^{\text {st }}$ November 1983.

CONVENTION on Wetlands of International Importance Especially as Waterfowl Habitat, opened for signature 2nd February 1971, 996 UNTS 245, entered into force 21st December 1975.

COOK, Catriona, Robin Creyke, Robert Geddes, David Hamer. Laying Down the Law. LexisNexis Butterworths, 8th ed. 2012.

DALES, J. H. Land Water and Ownership. Canadian Journal of Economics, 1, (4), 791, 1968. 
DRYZEK, John S. Politics of the Earth. Oxford University Press, 3rd ed. 2013.

\section{ENVIRONMENT PROTECTION AND BIODIVERSITY \\ CONSERVATION ACT, 1999. (Cth).}

FITZMAURICE, Andrew. The genealogy of Terra Nullius. Australian Historical Studies, 38(129) 1, 2007.

GUEST, Chris. Sharing the Water. Murray-Darling Basin Authority, 2016.

HART, Barry T. The Australian Murray-Darling Basin Plan: Factors leading to its successful development. Ecohydrology \& Hydrobiology, 229, 16, 2016.

JESSUP, Brad; RUBENSTEIN, Kim. Environmental Discourses in Public and International Law. Cambridge university Press, 2012. KOPINA, Helen; WASHINGTON, Haydn; TAYLOR, Bron; Piccolo, J. Anthropocentrism: more than just a misunderstood problem. Journal of Agricultural \& Environmental Ethics, 31 (1), 109, 2018.

MABO v Queensland (n. 2), 1992. 175 CLR 1.

MACK, Eric. John Locke. Bloomsbury Academic \& Professional, 2014. MURRAY-DARLING BASIN ROYAL COMMISSION. Report 2019. NATIONAL PARKS AND WILDLIFE ACT, 1974. (NSW).

NGARRINDJERI TENDI. Ngarrindjeri Heritage Committee, Ngarrindjeri Native Title Management Committee, Ngarrindjeri Nation Yarluwar-Ruwe Plan. Australian Government Department of the Environment and Energy. 2006. https://www.environment.gov.au/ indigenous/publications/pubs/ngarrindjeri-scp-2006-1.pdf.

PASCOE, Bruce. Dark Emu: Black seeds agriculture or accident? Magabala Books, 2013.

PRESTON, Brian J. The Australian Experience on Environmental Law. Environmental and Planning Law Journal, 35 (6), 637, 2018. 
RUBINSZTEIN-DUNLOP, Sean; Mary Fallon, Lucy Carter and Michael Slezak. How taxpayers are funding a huge corporate expansion in the Murray-Darling Basin. ABC News, Four Corners, Webpage, 8th July 2019. https://www.abc.net.au/news/2019-07-08/taxpayers-helping-fundmurray-darling-basin-expansion/11279468.

RUDOLPH, Sven and Elena Aydos, 'And Justice for All! Or: Justice in carbon market design: Insights from Theory and Experiences "Down Under”" ANZSEE Conference Blogs. Blog Post, December 2019. https://www.neweconomy.org.au/anzsee/blogs/and-justice-for-all/.

RUDOLPH, Sven, Elena Aydos, Takeshi Kawakatsu, and Achim Lerch , 'How to Build Truly Sustainable Carbon Markets'. Solutions, 9 (1), 2018. https://www.thesolutionsjournal.com/article/build-trulysustainable-carbon-markets/.

SCANLON, John. A hundred years of negotiations with no end in sight: Where is the Murray Darling Basin Initiative leading us? Environmental and Planning Law Journal, 386, 23 (5), 2006.

SPRAGUE. Blackstone's Commentaries, Abridged. Chicago: Callaghan and Co, 9th ed. 1915.

UNITED Nations Convention to Combat Desertification in Countries Experiencing Serious Drought and/or Desertification, Particularly in Africa, opened for signature $17^{\text {th }}$ June 1994, 1954 UNTS 3, entered into force $26^{\text {th }}$ December 1996.

UNITED Nations Framework Convention on Climate Change, opened for signature $9^{\text {th }}$ May 1992, 1771 UNTS 107, entered into force $21^{\text {st }}$ March 1994.

WALLIS, Lynley A.; GORMAN, Alice C. A time for change?

Indigenous heritage values and management practice in the Coorong and Lower Murray Lakes region, South Australia' 1 Australian Aboriginal Studies 57, 2010.

WATER ACT, 2007. (Cth). 
WEIR, Jessica, Lisa Strelein; MORGAN, Monica. Indigenous water rights within the Murray Darling Basin. Indigenous Law Bulletin, 17, 5, (29), 2003.

WRIGHT, Christopher; NYBERG, Daniel. Climate change, capitalism, and corporations: processes of creative self-destruction, Cambridge University Press, 2015. 41.

\section{Sally Ashton}

E-mail: Sally.Ashton@uon.edu.au

Socióloga pela Universidade de Newcastle. Doutoranda em Direito pela Universidade de Newcastle, Austrália.

Endereço profissional: The University of Newcastle (UON) 409 Hunter Street, Newcastle NSW 2308, Australia.

\section{Elena Aydos}

E-mail: elena.aydos@newcastle.edu.au https://orcid.org/0000-0002-8656-053X

Doutora em Direito pela Universidade de Sydney e Universidade de Tilburg. Professora sênior na Universidade de Newcastle, Austrália.

Endereço profissional: The University of Newcastle (UON) 409 Hunter Street, Newcastle NSW 2308, Australia. 